\title{
Correction to: Disabled Women, Care Regimes, and Institutionalised Homophobia: a Case Study From Poland
}

\author{
Agnieszka Wołowicz ${ }^{1}$ Agnieszka Król ${ }^{2}$ Justyna Struzik ${ }^{3}$ \\ Published online: 10 August 2021 \\ (c) The Author(s), under exclusive licence to Springer Science+Business Media, LLC, part of Springer Nature 2021
}

\section{Correction to: Sexuality Research and Social Policy https://doi.org/10.1007/s13178-021-00586-7}

The original version of this article unfortunately contained a mistake. The Abstract should read:

Introduction The intersection of non-heterosexuality, gender and disability became a prolific field of research among both queer, crip and disability studies scholars, though focusing mainly on Western regions. The article discusses how women narrate their everyday intimate and care-related experiences situated in ableist and heteronormative regimes of Central and Eastern Europe (CEE). The aim of this article is to scrutinise the care regimes as experienced, navigated and reported by non-heterosexual women with disabilities in Poland, a country characterized by institutionalisation, lack of individualised disability support, and state homophobia. Method The study is based on qualitative methods, namely semi-structured, in-depth interviews. We conducted interviews with 11 non-heterosexual disabled women living in Poland. The sampling was based on three criteria: gender, self-identification as a disabled person, and experience with being in a same-sex relationship (8 out of 11 participants were

The original article can be found online at https://doi.org/10.1007/ s13178-021-00586-7.

Agnieszka Wołowicz

a.wolowicz@uw.edu.pl

Agnieszka Król

a.krol@uj.edu.pl

Justyna Struzik

justyna.struzik@uj.edu.pl

1 Faculty of Education, University of Warsaw, Mokotowska 16/20, 00-561, Warszawa, Poland

2 Faculty of Medicine, Jagiellonian University Medical College, Krakow, Poland

3 Institute of Sociology, Jagiellonian University, Krakow, Poland in a homosexual relationship during the time of the interview). All eleven participants identified as non-heterosexual women (most as lesbians, one as bisexual and one as pansexual) and had a congenital physical disability (including cerebral palsy, spinal muscular atrophy, muscular dystrophy). None of the interviewees had an intellectual disability.

Results By tackling care regimes, our analysis explores women's experiences in the context of discursive confusions resulting from being at the intersection of often-contradictory local narrations on gender, disability, and sexuality. We identified three intertwined processes to understand and explore how care regimes work in Poland: (1) the separateness between queer and disabled policies and discourses, (2) the co-opting/ obscuring of homosexual relations between women by category of care, (3) familiarisation of care and its consequences for non-heterosexuality.

Policy Implication We suggest that social support systems must better address the needs of non-heterosexual women with disabilities which are profoundly impacted by structural, political and cultural constraints and possibilities.

The original article has been updated.

Publisher's Note Springer Nature remains neutral with regard to jurisdictional claims in published maps and institutional affiliations. 